\title{
Pelanggaran Hukum Internasional dalam Konflik Yaman Tahun 2015-2019 dan Akibatnya terhadap Situasi Krisis Kemanusiaan
}

\author{
Febriani Amalina Shalihah, Hasan Sidik \\ Program Studi Hubungan Internasional Fakultas IImu Sosial dan IImu Politik \\ Universitas Padjadjaran \\ e-mail : febriani17001@mail.unpad.ac.id
}

\begin{abstract}
This paper aims to review the violations of international laws regarding war crimes and crimes against humanity in the Yemeni conflict 2015-2019 and their consequences for the humanitarian crisis. The review is carried out by referring to non-international armed conflict and using the concepts of International Humanitarian Law, the Rome Statute, and International Human Rights Law. The research method is a qualitative research method using primary data sources from interviews and secondary data from literature studies through books, journals, and related official websites. The results show that many war crimes and crimes against humanity are committed by parties involved in the conflict, such as attacks on civilians and blockade of humanitarian aid supplies to Yemeni territory. These incidents constitute a violation of international law and create a humanitarian crisis in Yemen.
\end{abstract}

Keywords: crimes against humanity, humanitarian crisis, international law, Saudi Arabia, Yemen, war crimes.

\section{Abstrak}

Artikel ini bertujuan meninjau pelanggaran hukum internasional terkait tindakan kejahatan perang dan kejahatan terhadap kemanusiaan dalam konflik Yaman tahun 2015-2019 dan akibatnya terhadap situasi krisis kemanusiaan. Peninjauan dilakukan dengan merujuk pada situasi konflik bersenjata non-internasional dan acuan Hukum Humaniter Internasional, Statuta Roma, serta Hukum HAM Internasional. Metode penelitian yang digunakan adalah metode penelitian kualitatif dengan menggunakan sumber data primer yang berasal dari wawancara 
dan data sekunder yang berasal dari studi literatur melalui buku, jurnal, dan website resmi terkait. Hasil yang didapatkan menunjukkan banyaknya insiden kejahatan perang dan kejahatan terhadap kemanusiaan yang dilakukan oleh para pihak yang terlibat dalam konflik, di antaranya penyerangan terhadap penduduk sipil dan blokade pasokan bantuan kemanusiaan. Berbagai insiden ini merupakan pelanggaran terhadap hukum internasional dan memunculkan krisis kemanusiaan di Yaman.

Kata kunci: Arab Saudi, kejahatan kemanusiaan, kejahatan perang, krisis kemanusiaan, Yaman.

\section{Pendahuluan}

Setiap individu di seluruh dunia memiliki hak-hak dasar yang harus dipenuhi, seperti hak untuk hidup, hak untuk mendapatkan keamanan, serta hak untuk menjalani kehidupan yang bermartabat. Hak-hak dasar tersebut saat ini dikenal sebagai Hak Asasi Manusia (HAM) sebagaimana disebutkan dalam Universal Declaration of Human Rights (UDHR) yang dibentuk pada tahun 1948. Dengan adanya deklarasi ini, HAM menjadi hak universal bagi setiap individu yang harus dihormati dan dilindungi. Masih di rentang waktu yang sama dengan perkembangan HAM, muncul istilah crimes against humanity atau kejahatan terhadap kemanusiaan karena pada masa itu juga banyak terjadi pembunuhan masal atau yang kemudian dikenal dengan istilah genosida. Kejahatan terhadap kemanusiaan sendiri pada umumnya dipandang sebagai sesuatu yang berbeda dari HAM, namun seiring berjalannya waktu, kini genosida dan kejahatan lain terhadap kemanusiaan semakin dipandang sebagai bagian dari HAM (Clapham, 2007).

Sayangnya, meskipun telah ada deklarasi yang mengatur masalah HAM ini, dalam interaksi antar aktor hubungan internasional, baik negara maupun non-negara, ada kondisi-kondisi tertentu yang mengakibatkan terancamnya hak-hak tersebut, yang salah satu di antaranya adalah dalam konflik bersenjata. Oleh karenanya, dibuatlah aturan perang untuk melindungi orang-orang di wilayah konflik yang tidak terlibat dalam konflik itu sendiri, yakni Hukum Humaniter Internasional (HHI). Namun demikian, hukum ini seringkali dilanggar oleh pihak-pihak dalam konflik karena adanya kepentingan sehingga orang-orang yang tidak terlibat dalam konflik kembali terancam dan hak-hak dasarnya menjadi tidak terpenuhi.

Meskipun perang saat ini sudah bukan menjadi cara utama yang dipilih oleh negara dalam menyelesaikan masalah, tidak berarti konflik bersenjata menjadi hilang. Sebaliknya, konflik bersenjata masih banyak terjadi. Menurut data dari Peace Research 
Institute Oslo (PRIO), pada tahun 2017 diperkirakan ada 49 konflik bersenjata yang terjadi di seluruh penjuru dunia, dengan Timur Tengah sebagai wilayah dengan konflik terbanyak di dalamnya (Dupuy \& Rustad, 2018).

Salah satu negara di Timur Tengah yang masih mengalami konflik hingga saat ini adalah Yaman. Eskalasi konflik Yaman yang terjadi sejak tahun 2015 dan belum usai hingga kini (2021) menempatkan Yaman sebagai negara dengan krisis kemanusiaan terparah di dunia, sebagaimana dinyatakan oleh PBB pada tahun 2019 (UN, 2019). Konflik ini sendiri dilandasi oleh dua faktor utama, yakni penyatuan wilayah Yaman sejak tahun 1990 dengan perbedaan budaya dan aliran keagamaan di dalamnya serta ketidakpuasan sebagian masyarakat terhadap pemerintah Yaman setelah penyatuan tersebut. Ketidakpuasan ini juga diakibatkan oleh kondisi Yaman yang tidak sejahtera, baik secara ekonomi, sosial, maupun politik; antara lain dengan banyaknya praktik korupsi yang dilakukan pemerintah (Feierstein, 2019).

Saat peristiwa Arab Spring terjadi pada tahun 2011, tuntutan demokratisasi bermunculan berbagai negara Arab, termasuk di Yaman. Suku Houthi yang sejak tahun 2004 telah berkonflik dengan pemerintah Yaman yang dipimpin Ali Abdullah Saleh, dengan alasan bahwa Saleh mendukung AS serta melakukan penindasan dan diskriminasi (Dini, Diantha, \& Utari, 2017), pada masa Arab Spring ini bersama berbagai faksi lain di Yaman melakukan aksi demo besar-besaran menuntut reformasi. Transisi politik di Yaman ditandai dengan pengunduran diri Presiden Ali Abdullah Saleh dan digantikan oleh Abdrabbuh Mansur Hadi (Onasis, 2020).

Namun demikian, transisi ini tidak menjawab ketidakpuasan masyarakat sehingga konflik internal pun terus berlanjut. Dinamika politik semakin tereskalasi ketika kelompok Houthi (yang membentuk milisi Ansarullah) bergabung dengan pasukan yang setia kepada mantan Presiden Ali Abdullah Saleh, kemudian bergerak untuk menduduki Sana'a, ibukota Yaman pada tahun 2015. Presiden Mansur Hadi kemudian melarikan diri ke Arab Saudi dan meminta bantuan militer kepada negara-negara Liga Arab serta melayangkan surat permintaan bantuan kepada Dewan Keamanan PBB. Sehari pasca pengiriman surat tersebut, yaitu tanggal 26 Maret 2015, Arab Saudi bersama Qatar, Kuwait, Bahrain, dan Uni Emirat Arab melakukan serangan udara ke Yaman (Dini, Diantha, \& Utari, 2017). Pada tanggal 14 April 2015, Dewan Keamanan PBB mengeluarkan Resolusi 2216 yang antara lain berisi pengakuan atas pemerintahan Mansur Hadi, dan meminta semua pihak untuk mematuhi Dewan Kerjasama Teluk dan inisiatif lainnya dan untuk melanjutkan transisi politik yang dimediasi PBB.

Intervensi militer yang dilakukan Arab Saudi dan koalisinya telah mengakibatkan jutaan populasi Yaman menderita, di antaranya karena banyaknya insiden penyerangan 
yang dilakukan oleh para pihak yang berkonflik. Sebagai akibatnya, krisis kemanusiaan yang pada dasarnya sudah terjadi sejak sebelum terjadinya eskalasi konflik pun kian memburuk. Hal ini menjadikan ancaman terhadap kehidupan, keselamatan, kesejahteraan, dan hak-hak dasar penduduk sipil pun juga semakin besar seiring berlangsungnya konflik. Hal ini di antaranya dapat dilihat dari tingginya jumlah korban, yang sebagaimana dilaporkan oleh Office of the United Nations High Commissioner for Human Rights (OHCHR) pada November 2018, diperkirakan mencapai 6.872 korban tewas dan 10.768 korban terluka, yang mayoritas disebabkan oleh serangan udara koalisi Arab Saudi.

Beberapa tulisan terdahulu yang menjadi rujukan penulis adalah tulisan Gallardo, 2016; Dunning, 2018; Coppi, 2018; dan Sutrisna, 2017. Tulisan-tulisan tersebut memberikan pandangan mengenai krisis kemanusiaan Yaman serta implikasinya terhadap Hukum Humaniter Internasional ( $\mathrm{HHI}$ ) dan potensi terjadinya kejahatan kemanusiaan di Yaman, serta peran PBB dan keterlibatan negara-negara barat dan Australia dalam konflik tersebut. Dalam tulisan ini sendiri, periset akan mengkhususkan tinjauan kejahatan perang dan kejahatan terhadap kemanusiaan dalam konflik Yaman selama empat tahun (2015-2019) dengan merujuk pada HHI, Statuta Roma, dan Hukum HAM Internasional, serta menganalisis dampaknya terhadap situasi krisis kemanusiaan pada rentang tahun yang sama. Penelitian ini dilakukan secara kualitatif dengan sumber data primer didapatkan dari konvensi dan wawancara terstruktur dengan beberapa narasumber, sedangkan sumber data sekunder didapatkan dari studi literatur melalui buku, jurnal, serta website resmi terkait.

\section{Hukum Humaniter Internasional}

Hukum Humaniter Internasional (HHI) atau yang juga disebut sebagai "hukum perang" atau "hukum konflik bersenjata" terdiri dari aturan-aturan yang bertujuan untuk melindungi seseorang yang tidak atau tidak lagi terlibat dalam segala bentuk pertikaian. $\mathrm{HHI}$ yang terdiri dari hukum perjanjian internasional dan aturan kebiasaan ini juga secara spesifik ditujukan untuk menyelesaikan masalah kemanusiaan yang timbul sebagai akibat langsung dari konflik bersenjata, baik yang bersifat internasional maupun non-internasional (IPU \& ICRC, 2016).

$\mathrm{HHI}$ sendiri mendefinisikan konflik bersenjata internasional sebagai konflik yang terjadi antara dua negara atau lebih, sedangkan konflik bersenjata non-internasional sebagai konflik yang terjadi antara negara dan kelompok bersenjata non-negara atau antar kelompok bersenjata non-negara itu sendiri. Untuk dapat menjadi konflik bersenjata non-internasional sendiri, kelompok bersenjata tersebut harus memiliki kekuatan militer yang terorganisir-mampu merekrut anggota, merancang operasi 
militer, bernegosiasi untuk gencatan senjata, dan sebagainya; serta menguasai sebagian wilayah dari negara tempat di mana konflik tersebut berlangsung. Pun dijelaskan pula dalam $\mathrm{HHI}$ bahwa ketika konflik tersebut melibatkan pihak eksternal dengan persetujuan negara, maka pihak tersebut dianggap sebagai bagian dari konflik bersenjata non-internasional. Jika persetujuan ini tidak ada, barulah dimungkinkan adanya perluasan konflik menjadi konflik bersenjata internasional (Melzer \& Kutser, 2016)

Melzer \& Kutser (2016) juga menjelaskan bahwa dalam mengatur pertikaian dan melindungi para korban konflik bersenjata, $\mathrm{HHI}$ membebankan tugas-tugas tertentu dan melarang tindakan tertentu kepada mereka yang terlibat dalam konflik, salah satunya adalah terkait dengan prinsip pembedaan. Prinsip pembedaan yang merupakan landasan dari $\mathrm{HHI}$ ini mengatur pihak-pihak dalam konflik bersenjata untuk "setiap saat membedakan antara penduduk sipil dan militer, serta antara objek sipil dan sasaran militer, agar operasi yang dilakukan hanya diarahkan pada sasaran militer." Untuk itu, pengkategorian combatant dan non-combatant dan objek sipil dan militer sangat penting dalam hal ini.

Dua Hukum Humaniter Internasional yang akan digunakan dalam artikel ini yang salah satunya juga mengatur mengenai prinsip pembedaan tersebut adalah: 1) Konvensi Jenewa IV yang berisi aturan yang mengatur perlindungan penduduk sipil, khususnya perlakuan terhadap penduduk sipil di wilayah yang diduduki dan mereka yang dirampas kebebasannya, serta masalah pendudukan secara umum; 2) Protokol Tambahan II yang berisi jaminan mendasar bagi orang-orang yang tidak terlibat dalam konflik bersenjata non-internasional dan menetapkan aturan tentang perlindungan terhadap penduduk sipil, objek-objek sipil, dan instalasi yang penting untuk kelangsungan hidup penduduk sipil.

Kejahatan perang sendiri diidentifikasi sebagai serangkaian pelanggaran serius terhadap Konvensi Jenewa 1949 sebagaimana diidentifikasi dalam Konvensi Jenewa sendiri maupun Protokol Tambahan. Pelanggaran-pelanggaran ini kemudian dijelaskan dalam Statuta Roma 1998 Pasal 8 Ayat 2 yang menjelaskan mengenai kategori kejahatan perang.

\section{Hak Asasi Manusia}

Human Rights atau Hak Asasi Manusia (HAM) menurut OHCHR pada umumnya dipahami sebagai hak-hak yang melekat pada manusia. Konsep HAM ini mengakui bahwa setiap manusia berhak untuk menikmati hak asasinya tanpa membedakan ras, warna kulit, jenis kelamin, bahasa, agama, pendapat politik atau lainnya, asal kebangsaan atau sosial, properti, kelahiran, ataupun status lainnya. Hak-hak ini dijamin 
oleh hukum HAM internasional yang bersumber baik dari perjanjian, hukum internasional, hukum kebiasaan internasional, maupun deklarasi atau resolusi yang diadopsi oleh PPB.

Untuk menegaskan pentingnya perlindungan terhadap hak-hak dasar ini, dibentuklah Universal Declaration of Human Rights (UDHR) pada 10 Desember 1948. Deklarasi ini terdiri dari pembukaan dan 30 pasal yang menjabarkan mengenai HAM dan kebebasan mendasar yang menjadi hak semua pria dan wanita, tanpa perbedaan dalam bentuk apa pun. Deklarasi ini juga mengakui bahwa martabat yang melekat pada semua manusia adalah pondasi kebebasan, keadilan, dan perdamaian di dunia. Pengakuan akan martabat sebagaimana yang tersebut di atas dengan kata lain adalah pengakuan akan hak-hak dasar yang melekat pada setiap manusia, termasuk di antaranya adalah hak untuk hidup, kebebasan dan keamanan seseorang; hak atas standar hidup yang memadai; hak untuk mencari dan menikmati suaka dari penganiayaan di negara lain; hak atas kebebasan berpendapat dan berekspresi; hak atas pendidikan, kebebasan berpikir, hati nurani dan agama; dan hak untuk bebas dari penyiksaan dan perlakuan yang merendahkan.

Kejahatan terhadap kemanusiaan yang dilakukan terhadap seseorang dalam hal ini mengakibatkan tidak terpenuhinya HAM sehingga dalam menganalisis tindakan kejahatan terhadap kemanusiaan, selain merujuk pada Statuta Roma Pasal 7, penulis juga akan meninjau HAM apa saja yang tidak terpenuhi sebagai akibatnya dengan merujuk pada UDHR.

\section{Kejahatan Perang dan Kejahatan terhadap Kemanusiaan dalam Konflik Yaman Tahun 2015-2019}

Dalam meninjau tindakan-tindakan kejahatan perang dan kejahatan terhadap kemanusiaan yang terjadi dalam konflik Yaman, penulis merujuk pada Statuta Roma 1998, yaitu sebuah instrumen hukum yang mengidentifikasi empat kejahatan internasional, yakni kejahatan perang, kejahatan terhadap kemanusiaan, genosida, dan agresi. Istilah kejahatan terhadap kemanusiaan sendiri didefinisikan dalam Statuta Roma 1998 sebagai tindakan yang dilakukan sebagai bagian dari serangan yang meluas atau sistematis terhadap penduduk sipil. Sedangkan, istilah kejahatan perang diidentifikasi dalam Konvensi Jenewa dan Protokol Tambahan sebagai serangkaian pelanggaran serius terhadap $\mathrm{HHI}$, yang di dalamnya diatur mengenai tata cara berperang sehingga penduduk sipil atau orang-orang yang tidak terlibat dalam konflik terlindungi dari akibat konflik tersebut.

Kejahatan perang yang didefinisikan dalam Statuta Roma 1998 terbagi menjadi dua kategori, yakni tindakan kejahatan perang dalam konflik bersenjata internasional 
dan konflik bersenjata non-internasional. Konflik Yaman, sebagaimana dilaporkan dalam Group of Eminent International and Regional Experts on Yemen tahun 2019, merupakan konflik bersenjata non-internasional. Hal ini karena keterlibatan pihak eksternal seperti koalisi Arab Saudi dan UEA ke dalam konflik Yaman dilakukan dengan persetujuan Pemerintah Yaman yang diakui oleh komunitas internasional; sehingga konflik yang terjadi adalah antara Pemerintah Yaman (bersama negara pendukungnya, termasuk Arab Saudi) dan kelompok Houthi (dan faksi-faksi koalisinya). Milisi Houthi memenuhi syarat untuk disebut sebagai kelompok bersenjata non-negara, yang terlihat dari adanya kekuatan militer dan kemampuan untuk mengorganisir kekuatan militer tersebut serta penguasaan kelompok tersebut atas sebagian wilayah Yaman. Oleh karena itu, dalam menganalisis tindakan-tindakan kejahatan perang dalam konflik Yaman, penulis merujuk pada kategori tindakan kejahatan perang non-internasional berdasarkan Statuta Roma 1998 Pasal 8 Ayat 2. Dalam menganalisis tindakan-tindakan kejahatan terhadap kemanusiaan dalam konflik Yaman, penulis juga merujuk pada pengkategorian dalam Statuta Roma 1998 Pasal 7 Ayat 1.

Data tindakan kejahatan perang dan kejahatan terhadap kemanusiaan yang terjadi dalam konflik Yaman tahun 2015-2019 telah penulis rangkum dari beragam sumber sebagaimana terlihat dalam Tabel 1 dan Tabel 2 berikut ini.

Tabel 1. Data Kejahatan Perang dalam Konflik Yaman (2015 - 2019)*

\begin{tabular}{|c|c|c|c|c|}
\hline \multirow{2}{*}{ No } & \multirow{2}{*}{ Kategori } & \multirow{2}{*}{ Jumlah Kejahatan } & \multicolumn{2}{|c|}{ Total Korban Sipil } \\
\hline & & & Tewas & Terluka \\
\hline \multicolumn{5}{|c|}{ Statuta Roma Pasal 8 Ayat 2 (c) } \\
\hline 1 & $\begin{array}{l}\text { Kekerasan terhadap kehidupan dan } \\
\text { orang, khususnya pembunuhan dari } \\
\text { segala jenis, pemotongan anggota tubuh } \\
\text { (mutilasi), perlakuan kejam dan } \\
\text { penyiksaan. }{ }^{[1]}[2][3][4]\end{array}$ & 3.440 & $\begin{array}{l}6.410(730 \\
\text { perempuan dan } \\
1.399 \text { anak) }\end{array}$ & $\begin{array}{l}6.929 \text { (721 } \\
\text { perempuan dan } \\
1.378 \text { anak) }\end{array}$ \\
\hline 2 & $\begin{array}{l}\text { Melakukan kebiadaban terhadap } \\
\text { martabat orang, khususnya perlakuan } \\
\text { yang mempermalukan dan merendahkan } \\
\text { martabat. }\end{array}$ & \multicolumn{3}{|c|}{ Sama dengan poin (v) Statuta Roma Pasal 8 Ayat 2 (e). } \\
\hline 3 & Menahan sandera. ${ }^{[5]}$ & 16 & - & 16 \\
\hline 4 & $\begin{array}{l}\text { Dijatuhkannya hukuman dan } \\
\text { dilaksanakannya hukuman mati tanpa } \\
\text { keputusan yang dijatuhkan oleh suatu } \\
\text { pengadilan yang ditetapkan secara } \\
\text { reguler, yang menanggung semua } \\
\text { jaminan hukum yang pada umumnya } \\
\text { diakui sebagai tak terelakkan. }{ }^{[1][2]}\end{array}$ & 634 & 9 & 51 \\
\hline \multicolumn{5}{|c|}{ Statuta Roma Pasal 8 Ayat 2 (e) } \\
\hline
\end{tabular}




\begin{tabular}{|c|c|c|c|c|}
\hline \multirow{6}{*}{1} & $\begin{array}{l}\text { Secara sengaja melakukan serangan } \\
\text { terhadap penduduk sipil atau terhadap } \\
\text { masing-masing penduduk sipil yang tidak } \\
\text { ikut serta secara langsung dalam } \\
\text { pertikaian:[1] [4] }\end{array}$ & & & \\
\hline & 1. Serangan udara (Saudi/UEA) & 2.694 & $\begin{array}{c}5.550 \text { (639 } \\
\text { perempuan \& } \\
1052 \text { anak) }\end{array}$ & $\begin{array}{c}5.353 \text { (474 } \\
\text { perempuan \& } 720 \\
\text { anak) }\end{array}$ \\
\hline & 2. Serangan darat & 332 & $\begin{array}{l}606 \text { (74 } \\
\text { perempuan dan } \\
304 \text { anak) }\end{array}$ & $\begin{array}{c}1.233 \text { (165 } \\
\text { perempuan dan } \\
587 \text { anak) }\end{array}$ \\
\hline & 3. Ranjau darat & 156 & $\begin{array}{c}97 \text { (15 } \\
\text { perempuan dan } \\
41 \text { anak) }\end{array}$ & $\begin{array}{c}157 \text { (39 } \\
\text { perempuan dan } \\
66 \text { anak) }\end{array}$ \\
\hline & 4. Serangan drone AS & 13 & $\begin{array}{c}45(2 \\
\text { perempuan dan } \\
2 \text { anak) } \\
\end{array}$ & $\begin{array}{c}53 \text { (43 } \\
\text { perempuan dan } 5 \\
\text { anak) }\end{array}$ \\
\hline & 5. Targeted Killings & 90 & 90 & - \\
\hline 2 & $\begin{array}{l}\text { Secara sengaja melakukan serangan } \\
\text { terhadap gedung, material, satuan dan } \\
\text { angkutan serta personil medis yang } \\
\text { menggunakan lencana Konvensi Jenewa } \\
\text { sesuai dengan hukum internasional.[1] [8] }\end{array}$ & 139 & $\begin{array}{l}100 \text { ( } 6 \\
\text { perempuan dan } \\
10 \text { anak) }\end{array}$ & $\begin{array}{c}234 \text { (12 } \\
\text { perempuan dan } \\
28 \text { anak) }\end{array}$ \\
\hline 3 & $\begin{array}{l}\text { Secara sengaja melakukan serangan } \\
\text { terhadap personil, instalasi, material, } \\
\text { satuan atau kendaraan yang terlibat } \\
\text { dalam bantuan kemanusiaan atau misi } \\
\text { penjaga perdamaian sesuai dengan } \\
\text { Piagam Perserikatan Bangsa-Bangsa } \\
\text { sepanjang mereka berhak atas } \\
\text { perlindungan yang diberikan kepada } \\
\text { orang-orang dan objek-objek sipil } \\
\text { berdasarkan hukum perang. }{ }^{[3]}\end{array}$ & 62 & 27 & 20 \\
\hline 4 & $\begin{array}{l}\text { Secara sengaja melakukan serangan } \\
\text { terhadap gedung-gedung yang digunakan } \\
\text { untuk keperluan keagamaan, pendidikan, } \\
\text { kesenian, keilmuan atau sosial, } \\
\text { monumen bersejarah, rumah sakit dan } \\
\text { tempat-tempat di mana orang-orang } \\
\text { yang sakit dikumpulkan, dengan syarat } \\
\text { bahwa hal-hal tersebut bukan sasaran } \\
\text { militer. }{ }^{[4]}\end{array}$ & 595 & 479 & 520 \\
\hline 5 & $\begin{array}{l}\text { Melakukan perkosaan, perbudakan } \\
\text { seksual, pemaksaan prostitusi, kehamilan } \\
\text { paksa, sebagaimana ditetapkan dalam } \\
\text { pasal } 7 \text {, ayat } 2(\mathrm{f}) \text {, sterilisasi yang } \\
\text { dipaksakan, dan suatu bentuk lain } \\
\text { kekerasan seksual yang juga merupakan } \\
\text { pelanggaran serius terhadap pasal } 3 \text { yang } \\
\text { umum bagi empat Konvensi Jenewa. }{ }^{[3]}\end{array}$ & 631 & - & 631 \\
\hline
\end{tabular}




\begin{tabular}{|c|l|c|c|c|}
\hline 6 & $\begin{array}{l}\text { Memberlakukan wajib militer atau } \\
\text { mendaftar anak-anak di bawah umur } \\
\text { lima belas tahun ke dalam angkatan } \\
\text { bersenjata atau menggunakannya untuk } \\
\text { ikut serta secara aktif dalam pertikaian. }{ }^{6]}\end{array}$ & 3.646 & 625 & $\begin{array}{c}3.021 \text { terluka, } \\
\text { ditangkap, atau } \\
\text { ditahan }\end{array}$ \\
\hline 7 & $\begin{array}{l}\text { Mengatur perpindahan penduduk sipil } \\
\text { dengan alasan yang berkaitan dengan } \\
\text { sengketa, kecuali kalau keamanan orang- } \\
\text { orang sipil tersebut terancam atau alasan } \\
\text { militer yang amat penting } \\
\text { menuntutnya.[7] }\end{array}$ & 1 & - & - \\
\hline
\end{tabular}

Sumber: hasil olahan penulis

Tabel 2. Data Kejahatan terhadap Kemanusiaan dalam Konflik Yaman (2015-2019)*

\begin{tabular}{|c|c|c|c|c|}
\hline \multirow{2}{*}{ No } & \multirow{2}{*}{ Kategori } & \multirow{2}{*}{ Jumlah Kejahatan } & \multicolumn{2}{|c|}{ Total Korban Sipil } \\
\hline & & & Tewas & Terluka \\
\hline \multirow{6}{*}{1} & Pembunuhan: & & & \\
\hline & $\begin{array}{l}\text { 1. Serangan udara }{ }^{[4]} \\
\text { (Saudi/UEA) }\end{array}$ & 2.694 & $\begin{array}{c}5.550 \text { (639 } \\
\text { perempuan \& } \\
1052 \text { anak) }\end{array}$ & $\begin{array}{l}5.353(474 \\
\text { perempuan \& } \\
720 \text { anak) }\end{array}$ \\
\hline & 2. Serangan darat ${ }^{[1]}$ & 332 & $\begin{array}{l}606 \text { (74 } \\
\text { perempuan dan } \\
304 \text { anak) } \\
\end{array}$ & $\begin{array}{l}1.233(165 \\
\text { perempuan dan } \\
587 \text { anak) } \\
\end{array}$ \\
\hline & 3. Ranjau darat ${ }^{[1]}$ & 156 & $\begin{array}{l}97 \text { (15 perempuan } \\
\text { dan } 41 \text { anak) }\end{array}$ & $\begin{array}{l}157 \text { (39 } \\
\text { perempuan dan } \\
66 \text { anak) }\end{array}$ \\
\hline & $\begin{array}{l}\text { 4. Serangan drone } \\
\text { dan operasi darat } \\
\mathrm{AS}^{[1]}\end{array}$ & 13 & $\begin{array}{l}45 \text { ( } 2 \text { perempuan } \\
\text { dan } 2 \text { anak) }\end{array}$ & $\begin{array}{c}53 \text { ( } 43 \\
\text { perempuan dan } \\
5 \text { anak) }\end{array}$ \\
\hline & $\begin{array}{l}\text { 5. Targeted } \\
\text { Killings }^{[3]}\end{array}$ & 90 & 90 & - \\
\hline \multirow{3}{*}{2} & Pemusnahan: & & & \\
\hline & $\begin{array}{l}\text { 1. Pencegahan akses } \\
\text { bantuan } \\
\text { kemanusiaan }^{[8]}\end{array}$ & 275 & \multicolumn{2}{|c|}{$\begin{array}{l}\text { Setidaknya } 12 \text { juta orang kelaparan dan } \\
85.000 \text { anak-anak meninggal }\end{array}$} \\
\hline & $\begin{array}{l}\text { 2. Serangan terhadap } \\
\text { infrastruktur }{ }^{[4]}\end{array}$ & $\begin{array}{c}\text { Infrastruktur Ekonomi: } 1.358 \\
\text { Infrastruktur Publik dan Swasta: } \\
1.400\end{array}$ & $\begin{array}{l}1.394(68 \\
\text { perempuan dan } \\
130 \text { anak) }\end{array}$ & $\begin{array}{l}1.857 \text { ( } 30 \\
\text { perempuan dan } \\
87 \text { anak) }\end{array}$ \\
\hline 3 & Perbudakan** & $85.000^{[9]}$ & $\begin{array}{c}625 \text { (tentara } \\
\text { anak) }\end{array}$ & $\begin{array}{c}3.021 \text { terluka, } \\
\text { ditangkap, atau } \\
\text { ditahan (tentara } \\
\text { anak) }\end{array}$ \\
\hline 4 & $\begin{array}{l}\text { Deportasi atau } \\
\text { pemindahan paksa } \\
\text { penduduk. }{ }^{[7]}\end{array}$ & 1 kasus (2016) & - & \\
\hline
\end{tabular}




\begin{tabular}{|c|c|c|c|c|}
\hline 5 & $\begin{array}{l}\text { Perkosaan, perbudakan } \\
\text { seksual, pelacuran paksa, } \\
\text { kehamilan paksa, sterilisasi } \\
\text { paksa, atau segala bentuk } \\
\text { kekerasan seksual } \\
\text { lainnya.[3] }\end{array}$ & 631 & - & 631 \\
\hline 6 & $\begin{array}{l}\text { Pemenjaraan atau } \\
\text { perampasan kebebasan } \\
\text { fisik lainnya yang parah } \\
\text { yang melanggar aturan } \\
\text { dasar hukum } \\
\text { internasional. }^{[1]}[3]\end{array}$ & 634 & 9 & 51 \\
\hline 7 & Penyiksaan $^{[1]}$ & 155 & 22 & 133 \\
\hline 8 & $\begin{array}{l}\text { Penghilangan paksa } \\
\text { seseorang[1] }\end{array}$ & 369 & - & $\begin{array}{l}\text { Mayoritas turut } \\
\text { mendapatkan } \\
\text { penyiksaan } \\
\text { maupun } \\
\text { pelecehan } \\
\text { seksual di dalam } \\
\text { tahanan } \\
\end{array}$ \\
\hline 9 & Kejahatan apartheid. ${ }^{[11]}$ & \multicolumn{3}{|c|}{$\begin{array}{l}\text { Serangan koalisi Arab Saudi kepada kelompok Houthi dengan niat untuk } \\
\text { mengancurkan kelompok tersebut "secara keseluruhan atau sebagian" } \\
\text { dengan membunuh dan menyebabkan cedera tubuh yang serius (Lins, } \\
\text { 2019) }\end{array}$} \\
\hline
\end{tabular}

\section{Sumber: hasil olahan penulis ${ }^{1}$}

*Karena keterbatasan data, jumlah tersebut terbatas pada jumlah yang periset temukan dari berbagai laporan resmi organisasi terkait sehingga jumlahnya sangat mungkin jauh lebih banyak daripada yang terlihat dalam tabel. **Jumlah yang tercantum dalam kategori perbudakan mencakup perbudakan modern seperti perekrutan tentara anak, kerja paksa, perdagangan manusia, dsb. Namun, laporan resmi jumlah korban yang periset temukan dalam kategori ini hanya untuk tentara anak.

Berdasarkan data dalam kedua tabel tersebut, dapat terlihat bahwa terdapat setidaknya 9.164 insiden yang terkategori kejahatan perang dan 93.108 insiden yang

\footnotetext{
1] Sumber data tabel:

${ }^{[1]}$ Mwatana for Human Rights (2017), Mwatana for Human Rights (2018), Mwatana for Human Rights (2020).

${ }^{[2]}$ Amnesty International (2019).

[3] Group of Eminent International and Regional Experts on Yemen (2019)

${ }^{[4]}$ Yemen Data Project (2020)

${ }^{[5]}$ Human Rights Watch (2018).

[6] OCHA (2015, 2016, 2017,2018, 2019)

[7] Office of the United Nations High Commissioner for Human Rights (2018)

[9] Walk Free Foundation (2018)

${ }^{[10]}$ Alasrar (2020).

${ }^{[11]}$ Lins (2019)
} 
terkategori kejahatan terhadap kemanusiaan yang terjadi dalam konflik Yaman tahun 2015 - 2019. Melihat kategori dan insiden yang terjadi, banyak di antara insiden-insiden tersebut yang merupakan baik kejahatan perang maupun kejahatan terhadap kemanusiaan. Oleh karenanya, beberapa contoh insiden yang akan dipaparkan dalam bagian ini adalah insiden yang termasuk ke dalam keduanya, yakni: penyerangan terhadap penduduk sipil menggunakan senjata dengan dampak yang berdiameter luas di wilayah padat populasi; penyiksaan, penahahan sewenang-wenang, dan penghilangan paksa seseorang; serta pemusnahan yang dilakukan dengan penghalangan terhadap bantuan kemanusiaan dan penyerangan terhadap infrastruktur yang krusial bagi populasi untuk bertahan hidup. Ketiganya, dalam hal ini, merupakan insiden dengan dampak terparah terhadap populasi Yaman.

Sebagaimana terlihat dalam Tabel 1 dan 2, penyerangan terhadap penduduk sipil merupakan salah satu insiden terbanyak yang terjadi dalam konflik Yaman, yang mayoritas di antaranya merupakan serangan udara koalisi Arab Saudi dan UEA. Dari seluruh serangan udara koalisi, Yemen Data Project (2020) melaporkan bahwa mayoritas ditujukan terhadap objek-objek sipil. Termasuk di antara serangan tersebut adalah sepuluh serangan udara yang berdasarkan analisis para ahli semuanya dilaporkan menargetkan bangunan, kendaraan, pasar, dan hotel sipil, serta gedung pemerintah. Akibatnya 157 korban tewas dan 135 lainnya terluka, dengan 85 di antaranya adalah anak-anak di bawah umur. Bukan hanya koalisi, pihak Houthi pun di sisi lain juga melakukan penyerangan terhadap penduduk sipil, termasuk di dalamnya dengan menggunakan amunisi dan bahan peledak di daerah pemukiman sipil Ta'izz yang menewaskan 27 warga sipil (Qureshi, 2020).

Contoh insiden tersebut dapat dinyatakan sebagai kejahatan perang maupun kejahatan terhadap kemanusiaan sebagaimana didefinisikan dalam Statuta Roma 1998 dan telah melanggar Konvensi Jenewa IV Pasal 3 (1) dan Protokol Tambahan II Bagian IV Pasal 13 tentang perlindungan terhadap penduduk sipil, termasuk di dalamnya larangan untuk menjadikan penduduk sipil sebagai objek serangan. Pun, panel ahli juga menyimpulkan bahwa tindakan tersebut menunjukan tidak dihormatinya prinsip pencegahan dalam $\mathrm{HHI}$, tidak ada bukti bahwa warga sipil yang menjadi sasaran terlibat dalam permusuhan, dan kerugian yang ditimbulkan terhadap warga sipil tidak sebanding dengan keuntungan militer. Sebagai akibatnya, HAM populasi Yaman yang dinyatakan dalam Pasal 3 Universal Declaration of Human Rights bahwa setiap orang berhak atas penghidupan dan keselamatan, kebebasan, dan keselamatan individu juga tidak terpenuhi.

Kemudian, dalam hal penyiksaan dan perlakuan tidak manusiawi, penulis menemukan adanya pernyataan dari mantan tahanan Houthi yang mengatakan bahwa 
mereka mendapatkan kekerasan selama ditahan (Human Rights Watch, 2018). Koalisi Saudi, dalam hal ini UEA, menjalankan tiga fasilitas penahanan yang terletak di Mukalla, Aden, dan Balhalf yang juga dilaporkan telah bertindak melanggar HHI dan Hukum HAM Internasional terkait perlakukan kekerasan kepada tahanan. Pemerintah Yaman juga dilaporkan melakukan pelanggaran yang sama atas 23 orang yang ditahan di Aden Ma'rib, dan Lahij (International Observatory Human Rights, 2018).

Dirangkum dari beberapa sumber, dalam kebanyakan kasus, para ahli menemukan bahwa para tahanan tidak diberi tahu alasan dari penangkapan mereka, tidak dituntut, tidak diberi akses ke pengacara ataupun hakim, serta ditahan tanpa komunikasi untuk waku yang lama atau bahkan tidak terbatas (BBC, 2018). Penyiksaan dan penahanan sewenang-wenang tersebut dapat dikategorikan baik sebagai kejahatan perang maupun kejahatan terhadap kemanusiaan. Keduanya telah melanggar di antaranya Konvensi Jenewa Pasal 71 dan Protokol Tambahan Pasal 6 yang telah mengatur mengenai diharuskannya proses pengadilan sebelum memutuskan atau menjatuhkan hukuman atas pelanggaran tindak pidana yang dilakukan oleh seseorang terkait dengan konflik bersenjata. Insiden tersebut juga telah melanggar HAM internasional yang dijamin dalam Universal Declaration of Human Rights Pasal 7-11 yang menyatakan hak seseorang atas perlindungan, kesamaan, dan keadilan hukum.

Insiden lain yang sangat berdampak pada situasi krisis kemanusiaan Yaman adalah tindakan pemusnahan yang merupakan kejahatan terhadap kemanusiaan. Pemusnahan yang dimaksud dalam kategori kejahatan terhadap kemanusiaan dalam Statuta Roma 1998 mencakup gangguan yang disengaja terhadap kondisi kehidupan, antara lain perampasan akses ke makanan dan obat-obatan yang terhitung menyebabkan kehancuran sebagian populasi. Dalam konflik Yaman tahun 2015-2019, terjadi pencegahan terhadap masuknya bantuan kemanusiaan. Sejak Maret 2015, koalisi yang dipimpin oleh Arab Saudi secara sistematis telah menghalangi bantuan kemanusiaan untuk menjangkau penduduk sipil dengan menerapkan blokade laut, darat, dan udara yang disebutkan merupakan bagian dari upaya melawan Houthi. Blokade ini juga membatasi masuknya makanan, bahan bakar, dan obat-obatan di negara yang menghimpor sebesar 80 hingga 90\% memenuhi kebutuhannya (International Comission of Jurist, 2018).

Pertempuran dan blokade parsial yang dilakukan oleh koalisi juga telah menyebabkan 22 juta orang membutuhkan bantuan kemanusiaan, menciptakan darurat keamanan pangan terbesar di dunia, serta menyebabkan wabah kolera yang diperkirakan telah memengaruhi 1,1 juta orang di Yaman (BBC, 2018). Blokade total yang diterapkan ini juga dianggap telah melanggar aturan dasar $\mathrm{HHI}$ mengenai penghambatan bantuan kemanusiaan bagi penduduk yang membutuhkan dan disebut 
sebagai 'penggunaan ancaman kelaparan sebagai alat tawar menawar dan alat perang' oleh panel ahli DK PBB dalam laporan mereka tahun 2018 (Global Rights Compliance \& World Peace Foundation, 2019). Bukan hanya koalisi, penghalangan masuknya bantuan kemanusiaan ke sejumlah populasi juga dilakukan oleh milisi Houthi, berdasarkan data dari Mwatana for Human Rights (2017).

Blokade total yang dilakukan koalisi Saudi memberikan dampak terbesar terhadap kondisi kemanusiaan Yaman. Kombinasi dari krisis ekonomi dan taktik ekonomi telah menghasilkan krisis pangan besar di Yaman yang memenuhi kategori kondisi kelaparan (famine) yang berpengaruh pada nasib generasi selanjutnya. Wakil Sekretaris Jenderal PBB untuk Urusan Kemanusiaan dan Koordinator Bantuan Darurat, Stephen O'Brien, dalam pernyataannya di depan Sidang Dewan Keamanan dalam isu Yaman, mengatakan bahwa anak-anak mengalami penderitaan yang suram, dengan meninggalnya anak di bawah usia lima tahun setiap 10 menit karena penyebab yang sebenarnya bisa dicegah (OCHA, 2017). Jumaan (2020) dalam wawancara bersama penulis juga mengatakan bahwa dampak dari blokade ini bahkan bisa terbilang lebih buruk daripada dampak konfliknya sendiri dan ia mengatakan bahwa menghentikan konflik saja tidak akan cukup untuk mengatasi krisis kemanusiaan Yaman bila blokade tersebut masih diterapkan.

Selain blokade, perusakan meluas yang tidak dibenarkan oleh kebutuhan militer dan dilakukan secara tidak sah dan tanpa alasan yang dilakukan oleh para pihak terhadap infrastruktur yang penting bagi keberlangsungan hidup populasi juga menjadi salah satu bentuk pemusnahan lainnya. Penyerangan terhadap infrastruktur ini, sebagaimana terlihat dalam Tabel 2, mencapai setidaknya 2.758 insiden, yang mayoritas oleh serangan udara koalisi. Termasuk di antara serangan tersebut 800 serangan udara yang ditargetkan pada pasar makanan dan 500 lainnya terhadap gudang makanan. Studi lapangan yang dilakukan oleh Kementerian Pertanian Yaman juga melaporkan bahwa serangan koalisi setidaknya telah menghancurkan 270 bangunan dan peralatan pertanian, 43 asosiasi pertanian, 9.017 saluran irigasi air tradisional, setidaknya 1.834 pompa air, 10.170 jaringan irigasi modern, 33 unit irigasi bertenaga surya, 54 pasar pertanian, dan 45 pusat ekspor ekspor (Organization for Defending Victims of Violence, 2020).

\section{Krisis Kemanusiaan Yaman}

Situasi krisis kemanusiaan Yaman dengan tindakan kejahatan perang dan kejahatan terhadap kemanusiaan memiliki relevansi yang sangat erat mengingat dampaknya terhadap populasi Yaman bersinggungan antara satu sama lain. Sebagai contoh, banyaknya jumlah insiden penyerangan terhadap penduduk sipil dengan jumlah 
korban sipil dan kebutuhan perlindungan bagi populasi Yaman. Contoh lainnya, penyerangan terhadap infrastruktur medis, air, dan pangan terhadap krisis kesehatan, air bersih dan sanitasi, serta kelaparan yang dihadapi oleh populasi Yaman. Pelaku berbagai insiden tersebut, menurut sejumlah referensi dalam riset ini, adalah semua pihak yang terlibat dalam konflik ini.

Krisis kemanusiaan Yaman dapat dikategorikan sebagai kondisi keadaan darurat politik yang kompleks atau suatu fenomena yang merupakan krisis buatan manusia, di mana situasi kekerasan mengakibatkan kematian manusia, pemindahan paksa, epidemi, dan kelaparan (Francesch, et al., 2010). International Federation of the Red Cross (IFRC), secara lebih spesifik mendeskripsikan kedaruratan kompleks sebagai krisis kemanusiaan di suatu negara, wilayah atau masyarakat di mana terdapat perusakan total atau yang cukup besar akibat dari konflik internal atau eksternal dan yang memerlukan respons internasional yang melampaui mandat atau kapasitas lembaga tunggal mana pun dan/atau program PBB yang sedang berjalan (IASC) (IFRC, t.t.)

Berikut ini tinjauan penulis mengenai krisis kemanusiaan Yaman dengan merujuk pada keenam kedaruratan kompleks yang dikemukakan oleh IFRC. Tinjauan ini dirangkum dari Yemen Humanitarian Needs Overview (HNO Yaman) tahun 2015-2019 yang dikeluarkan oleh United Nations Office for the Coordination of Humanitarian Affairs (OCHA), serta beberapa sumber lainnya seperti Yemen Data Project, laporan PBB, serta data-data dari organisasi internasional terkait seperti UNICEF, WHO, dan UNHCR.

\section{Kekerasan luas dan hilangnya nyawa}

HNO Yaman tahun 2015 melaporkan jumlah korban sipil meninggal akibat konflik diperkirakan mencapai 1.297 orang dan jumlah korban terluka mencapai 5.028 orang. Empat tahun berselang, HNO Yaman 2019 melaporkan jumlah total dari korban tewas dan terluka mencapai 17.700 orang atau bertambah 11.375 orang, hampir dua kali lipat (179\%) dari tahun 2015. Akibatnya, jumlah populasi yang membutuhkan perlindungan pun turut meningkat dari tahun 2015 yang berjumlah 11,4 juta orang menjadi 14,4 orang pada tahun 2019, dengan 8,2 juta di antaranya dalam kondisi acute need (kebutuhan akut).

\section{Perpindahan populasi}

Perpindahan populasi yang dihitung berdasarkan jumlah Internally Displaced Persons (IDPs) selama konflik Yaman tahun 2015-2019 cukup fluktuatif setiap tahunnya, namun secara umum meningkat dalam jangka waktu empat tahun. Pada Mei 2015, tiga bulan setelah eskalasi konflik, dilaporkan terdapat sekitar satu juta orang yang menjadi IDPs. Jumlah ini meningkat pesat dari yang semula hanya berjumlah 334.000 orang pada 
Desember 2014 (OCHA, 2015). Pada Desember 2019, jumlah ini telah bertambah menjadi 3,6 juta orang (OCHA, 2019) atau meningkat sebesar lebih dari 10 kali lipat sejak Desember 2014 dan sekitar 3,5 kali lipat dari Mei 2015. Peningkatan jumlah IDPs dalam selang waktu empat tahun ini telah mengakibatkan jumlah orang yang memerlukan tempat penampungan darurat dan keperluan rumah tangga turut meningkat. Hanya dalam waktu 12 bulan (Februari 2018 - Februari 2019) peningkatan tempat penampungan diperkirakan mencapai hampir setengah kali lipat (UN, 2019).

\section{Kerusakan luas pada masyarakat dan ekonomi}

Kerusakan luas pada masyarakat dan ekonomi di antaranya terlihat dari banyaknya orang yang memerlukan bantuan kemanusiaan. Dilaporkan dalam HNO Yaman 2015, terdapat 21,1 juta orang yang memerlukan bantuan kemanusiaan, atau sebanyak $80 \%$ dari total populasi Yaman pada saat itu. Jumlah ini telah mengalami peningkatan sebesar 33\% dari akhir tahun 2014 (sebelum eskalasi konflik terjadi), yang berjumlah 15,9 juta orang. Hal ini menunjukan bahwa eskalasi konflik memberikan perbedaan yang sangat signifikan terhadap krisis kemanusiaan Yaman. Kemudian, dalam jangka waktu empat tahun, HNO Yaman dan laporan PBB tahun 2019 melaporkan bahwa jumlah tersebut mencapai sekitar 24 juta orang, dengan 12 juta di antaranya adalah anak-anak (UNICEF, 2019).

Yaman sangat bergantung pada impor makanan dan bahan bakar komersial untuk memenuhi kebutuhan dasarnya. Akibat pembatasan impor, termasuk karena blokade yang diberlakukan oleh para pihak yang berkonflik, dan konflik itu sendiri, Yaman mengalami kekurangan pangan, bahan bakar, air, dan persediaan dasar lainnya. Akibatnya, harga bahan bakar pun meningkat empat kali lipat, yang mendorong harga makanan dan air menjadi semakin jauh dari jangkauan masyarakat. HNO Yaman 2015 melaporkan bahwa sejak eskalasi konflik, otoritas pemerintah memperkirakan bahwa Produk Domestik Bruto (PDB) per kapita terkonstraksi sekitar 35\% dan inflasi meningkat sebesar $30 \%$.

Dalam jangka waktu tiga tahun, HNO Yaman 2019 melaporkan bahwa kontraksi ini meningkat menjadi hampir 50\% dengan kerugian kumulatif PDB riil diperkirakan mencapai USD 49,9 miliar dan inflasi diperkirakan telah meningkat hingga lebih dari 40\% (OCHA, 2019). Akibatnya, tingkat kemiskinan juga telah meningkat secara dramatis, dengan perkiraan $81 \%$ populasi Yaman sekarang berada di bawah garis kemiskinan, atau meningkat sebesar sepertiga sejak 2014 (OCHA, 2019). Akibatnya, tingkat kemiskinan juga telah meningkat secara dramatis, dengan perkiraan $81 \%$ populasi Yaman sekarang berada di bawah garis kemiskinan, atau meningkat sebesar sepertiga sejak 2014 (OCHA, 2019). Bank Dunia (2019) juga menyebutkan bahwa kemiskinan diproyeksikan akan 
tetap tinggi dengan lebih dari tiga perempat populasi pada tahun 2019 hidup dengan pendapatan di bawah USD 3,20 per hari dan sekitar setengah dari populasi hidup dengan pendapatan di bawah USD 1,90 per hari. Hal ini mengakibatkan bantuan luar negeri besar-besaran akan terus diperlukan untuk memulihkan layanan dasar dan mendanai pemulihan dan rekonstruksi dalam periode pasca konflik (World Bank, 2019).

\section{Kebutuhan akan bantuan kemanusiaan berskala besar dan dalam beragam aspek (multi-faceted)}

Penulis membagi kebutuhan ini ke dalam lima aspek, yakni kesehatan, air bersih dan sanitasi, pangan, pendidikan dan anak-anak, serta perlindungan dari kekerasan berbasis gender. Dari aspek kesehatan, dilaporkan bahwa konflik mengakibatkan populasi Yman mengalami kesulitan dalam mengakses fasilitas kesehatan, bahkan yang paling dasar sekalipun. HNO Yaman 2016 memperkirakan bahwa populasi yang membutuhkan fasilitas kesehatan dasar mencapai 14,8 juta orang. Hal ini di antaranya disebabkan oleh berhenti berfungsinya 600 fasilitas kesehatan karena kerusakan terkait konflik atau kekurangan bahan bakar, staf dan persediaan (OCHA, 2016). Jumlah ini kemudian meningkat menjadi 19,7 persen pada tahun 2019 dengan hanya sekitar 51\% fasilitas kesehatan di Yaman yang masih berfungsi penuh (OCHA, 2019).

Tidak memadainya fasilitas kesehatan ditambah dengan krisis air bersih dan sanitasi juga mengakibatnya tersebarnya wabah kolera di wilayah Yaman. Dilaporkan dalam HNO Yaman 2015, sekitar 20,4 juta orang atau kurang lebih $80 \%$ dari populasi Yaman pada saat itu membutuhkan bantuan air dan sanitasi (OCHA, 2015). Jumlah tersebut terlihat mengalami penurunan dalam HNO Yaman 2017, 2018, dan 2019 menjadi 14,5 juta, 16,4 juta, dan 17,8 juta orang. Penurunan ini, dijelaskan dalam keterangan HNO Yaman 2017 terjadi karena perubahan metode yang memengaruhi perubahan angka yang didapatkan sehingga tidak berarti kondisinya telah membaik.

Selain krisis air bersih dan sanitasi, krisis lainnya yang juga mengakibatkan masalah kesehatan adalah krisis pangan. Berdasarkan HNO Yaman tahun 2015, dalam rentang waktu tiga bulan sejak perluasan konflik terjadi, yakni Maret 2015, jumlah populasi yang mengalami ketidakamanan pangan meningkat sebesar $15,7 \%$ menjadi 12,3 juta orang (sekitar 50\% dari total populasi Yaman pada saat itu) (OCHA, 2015). Jumlah ini meningkat drastis pada HNO Yaman 2019 menjadi 20,1 juta orang, dengan 10 juta di antaranya dalam kondisi kelaparan esktrem. Artinya, peningkatan krisis pangan berbanding lurus dengan peningkatan jumlah orang yang mengalami malnutrisi selama konflik ini berlangsung pada tahun 2015-2019.

Dari aspek lainnya, yakni perlindungan anak dan pendidikan, HNO Yaman melaporkan bahwa selama konflik Yaman berlangsung pada tahun 2015-2019, terdapat 
banyak pelanggaran terhadap Hak Asasi Manusia (HAM) terhadap anak-anak. Selain pelanggaran dalam bentuk fisik berupa serangan langsung, kasus pekerja anak dan perekrutan tentara anak juga banyak terjadi. UN Committee on the Rights of the Child pada Oktober 2018 menyebutkan hal tersebut mengakibatkan banyak anak mengalami cacat dan meninggal, serta trauma akibat operasi militer (Human Rights Watch, 2019). HNO Yaman 2019 juga melaporkan bahwa terdapat 4,3 juta anak yang membutuhkan perlindungan sebagai akibat dari 2.367 kasus pelanggaran berat terhadap anak-anak antara Oktober 2017 - September 2018. Bukan itu saja, 4,7 juta anak juga dilaporkan membutuhkan bantuan pendidikan, dengan 2 juta di antaranya tidak bersekolah sama sekali (OCHA, 2019). Jumlah ini meningkat dari 2,9 juta anak yang membutuhkan bantuan akses ke pendidikan yang dilaporkan dalam HNO Yaman 2015.

\section{Adanya penghalang atau pencegahan bantuan kemanusiaan oleh kendala politik dan militer}

Dengan kondisi krisis kemanusiaan yang sangat parah, populasi Yaman kini sangat bergantung pada impor dan bantuan kemanusiaan untuk memenuhi kebutuhan dasarnya. Namun, sebagaimana dilaporkan dalam HNO Yaman 2016, pembatasan impor yang diperlakukan oleh Koalisi Saudi dan hambatan lokal yang diberlakukan oleh Houthi menghambat pengiriman pasokan kritis kepada populasi yang membutuhkan. Salah satu dampaknya adalah terputusnya bantuan terhadap 250.000 orang di Aden dan Ta'izz hingga pertengahan Oktober 2015 (OCHA, 2016). Kesulitan penyaluran bantuan kemanusiaan ini juga terjadi karena serangan udara terhadap infrastruktur penting seperti pelabuhan (OCHA, 2017), serta penundaan penerbitan izin dari Koalisi Saudi untuk kapal kontainer komersial yang membawa makanan dan barang-barang kemanusiaan ke Yaman sebagaimana dilaporkan oleh Mekanisme Verifikasi dan Inspeksi PBB untuk Yaman (UNVIM) (OCHA, 2018). Selain blokade logistik, pangan, dan medis ke dalam Yaman, Human Rights (HRW) juga menyebutkan bahwa penerbangan ke luar pun juga dibatasi, di antaranya ketika ribuan warga sipil berusaha mengungsi akibat pertempuran ke pantai barat Yaman pada tahun 2017 dan 2018 (Human Rights Watch, 2019).

\section{Risiko keamanan yang signifikan bagi pekerja bantuan kemanusiaan di beberapa wilayah}

Hal terakhir yang juga penting dalam krisis kemanusiaan Yaman adalah keselamatan para pekerja kemanusiaan yang terancam selama konflik berlangsung pada tahun 2015- 2019 karena para pihak yang melakukan serangan langsung terhadap petugas kesehatan maupun fasilitas kesehatan seperti rumah sakit. Sejak tahun 2015, insiden yang tercatat sebagai serangan terhadap perawatan kesehatan mencapai 120 
insiden (OCHA, 2019). Insiden tersebut di antaranya dilaporkan dalam HNO Yaman 2016 yang menyebutkan bahwa terdapat 27 kasus pembajakan ambulan, delapan petugas kesehatan terbunuh serta 20 lainnya terluka. Kemudian, 274 fasilitas kesehatan juga dilaporkan telah rusak atau hancur dalam konflik (OCHA, 2017). Artinya, bukan hanya mengancam keamanan populasi, konflik Yaman tahun 2015-2019 juga turut mengancam keselamatan dari pekerja kemanusiaan yang semestinya dilindungi berdasarkan $\mathrm{HHI}$.

\section{Simpulan}

Berdasarkan hasil analisis yang dilakukan, penulis menyimpulkan bahwa sejak tahun 2015-2019 terdapat banyak insiden kejahatan perang dan kejahatan terhadap kemanusiaan yang dilakukan oleh semua pihak yang terlibat dalam konflik Yaman. Insiden tersebut mencapai setidaknya mencapai 9.164 insiden (yang terdiri dari 10/14 kategori kejahatan perang berdasarkan Statuta Roma 1998) dan kejahatan terhadap kemanusiaan yang setidaknya mencapai 93.108 insiden yang dilakukan oleh para pihak dalam konflik (yang terdiri dari 10/11 kategori kejahatan terhadap kemanusiaan berdasarkan Statuta Roma 1998 dan termasuk di antaranya insiden kejahatan perang yang juga termasuk ke dalam kejahatan terhadap kemanusiaan). Insiden tersebut juga menunjukkan bahwa para pihak yang terlibat dalam konflik tidak menghormati $\mathrm{HHI}$, khususnya Konvensi Jenewa IV, Protokol Tambahan II, serta hukum kebiasaan internasional; dan secara langsung juga mengakibatkan tidak terpenuhinya HAM dari populasi Yaman yang diakui secara internasional dalam UDHR, termasuk yang paling dasar sekalipun seperti hak atas penghidupan dan keselamatan, kebebasan, dan keselamatan individu yang dinyatakan dalam Pasal 3. Akibatnya, krisis kemanusiaan Yaman sejak terjadinya eskalasi konflik tahun 2015 sampai dengan tahun 2019 pun menjadi semakin parah setiap tahunnya, terlihat dari peningkatan jumlah korban serta jumlah populasi yang membutuhkan bantuan perlindungan dan kemanusiaan.

Statuta Roma 1998 telah memberikan kerangka penegakan hukum atas tindak kejahatan internasional, yakni melalui ICC (International Criminal Court). Namun, karena ICC sendiri hanya mengikat negara penandatangan, hal ini akan sulit untuk diterapkan pada konflik Yaman di mana pihak-pihak yang terlibat belum meratifikasi Statuta Roma 1998. Oleh karenanya, hal lain yang dapat dilakukan sebagaimana direkomendasikan oleh para ahli adalah membuat pengadilan ad hoc dan badan investigasi khusus untuk menindak pelaku kejahatan perang dan kejahatan terhadap kemanusiaan dalam konflik Yaman, serta menuntut negara-negara pemasok senjata seperti AS dan Inggris untuk segera menghentikan pasokan senjata mereka yang berpengaruh secara signifikan terhadap penyerangan-penyerangan yang dilakukan terhadap populasi Yaman. 


\section{Daftar Pustaka}

Alasrar, F. A., 2020. Yemen's Pied Piper: A Child Soldier Tragedy. [Online] Dalam: https://insidearabia.com/yemens-pied-piper-a-child-soldier-tragedy/

Amnesty International, 2019. HUMAN RIGHTS IN THE MIDDLE EAST AND NORTH AFRICA: REVIEW OF 2018, London: Amnesty International.

BBC, 2018. Yemen's Houthi rebels taking and torturing hostages - HRW. [Online] Dalam: https://www.bbc.com/news/world-middle-east-45639276

Clapham, A., 2007. Human Rights: A Very Short Introduction. Oxford: Oxford University Press.

Dini, R. J., Diantha, I. M. P. \& Utari, A. S., 2017. Tinjauan Yuridis Intervensi Militer Koalisi Arab Saudi dalam Konflik Bersenjata di Yaman. Kertha Negara, 5(4), pp. 1-19.

Dupuy, K. \& Rustad, S., 2018. Trend in Armed Conflict, 1947-2017, Gronland: Peace Research Institute Oslo.

Feierstein, G. M., 2019. Yemen: The 60-Year War. Washington D. C.: Middle East Institute.

Francesch, M. C. et al., 2010. Alert 2010! Report on conflicts, human rights and peacebuilding. Barcelona: Icaria Editorial/Escola de Cultura de Pau, UAB.

Global Rights Compliance \& World Peace Foundation, 2019. The Crime of Starvation and Methods of Prosecution and Accountability, Den Haag: Global Rights Compliance.

Group of Eminent International and Regional Experts on Yemen, 2019. Situation of human rights in Yemen, including violations and abuses since September 2014, Geneva: United Nations High Commissioner for Human Rights.

Human Rights Watch, 2018. Yemen: Houthi Hostage-Taking Arbitrary Detention, Torture, Enforced Disappearance Go Unpunished. [Online] Dalam: https://www.hrw.org/news/2018/09/25/yemen-houthi-hostage-taking

Human Rights Watch, 2019. Yemen Events of 2018. [Online] Dalam: https://www.hrw.org/world-report/2019/country-chapters/yemen

IFRC, t.thn. Complex/manmade hazards: complex emergencies. [Online] Dalam: https://www.ifrc.org/en/what-we-do/disaster-management/aboutdisasters/definition-of-hazard/complex-emergencies/ [Diakses September 2020]. 
International Comission of Jurist, 2018. Bearing the Brunt of War in Yemen: International Law Violations and their Impact on the Civilian Population, Geneva: International Comission of Jurist.

International Observatory Human Rights, 2018. Neglected Nation: The Humanitarian Crisis in Yemen, London: International Observatory Human Rights.

IPU \& ICRC, 2016. International Humanitarian Law. s.I.:IPU and ICRC.

Jumaan, A. O., 2020. Conflict and Humanitarian Crisis in Yemen [Wawancara] (11 September 2020).

Lins, R., 2019. CONFLICT IN YEMEN: MORE THAN A CONFLICT. [Online] Dalam: http://worldwithoutgenocide.org/genocides-and-conflicts/conflict-in-yemen

Mwatana for Human Rights, 2017. Woes of "Arabia Felix": Situation of Human Rights in Yemen 2017, Sana'a: Mwatana for Human Rights.

Mwatana for Human Rights, 2018. Withering Life: Human Rights Situation in Yemn 2018, Sana'a: Mwatana for Human Rights.

Mwatana for Human Rights, 2020. Without Accountability: Human Rights Situation in Yemen 2019, Sana'a: Mwatana for Human Rights.

OCHA, 2015. Yemen Humanitarian Needs Overveiw 2015, New York: OCHA.

OCHA, 2016. Yemen Humanitarian Needs Overview 2016, New York: OCHA.

OCHA, 2017. Yemen Humanitarian Needs Overview 2017, New York: OCHA.

OCHA, 2017. Yemen: A child under the age of five dies every 10 minutes of preventable causes - UN Humanitarian Chief. [Online]

Dalam: https://www.unocha.org/es/story/yemen-child-under-age-five-dies-every-10minutes-preventable-causes-un-humanitarian-chief

OCHA, 2018. Yemen Humanitarian Needs Overview 2018, New York: OCHA.

OCHA, 2019. Yemen Humanitarian Needs Overview 2019, New York: OCHA.

Office of the United Nations High Commissioner for Human Rights, 2018. Summary of Stakeholders' submissions on Yemen, New York: United Nation.

Onasis, A., 2020. Konstruksi Identitas sebagai Stimulus Intervensi Arab Saudi dan Amerika Serikat dalam Perang Saudara Yaman. [Online] Dalam: https://www.researchgate.net/publication/342397129_Konstruksi_Identitas_seba 
gai_Stimulus_Intervensi_Arab_Saudi_dan_Amerika_Serikat_dalam_Perang_Sauda ra_Yaman [Diakses Oktober 2020].

Organization for Defending Victims of Violence, 2020. Annual full-day meeting on the rights of the child (theme: "Realizing the rights of the child through a healthy environment"), New York: United Nation.

Qureshi, W. A., 2020. The Crisis in Yemen: Armed Conflict and International Law. North Carolina Journal of International Law Volume 45 No. 1, pp. 228-268.

UN, 2019. Humanitarian crisis in Yemen remains the worst in the world, warns UN. [Online] Dalam: https://news.un.org/en/story/2019/02/1032811 [Diakses September 2020].

UN, 2019. Humanitarian crisis in Yemen remains the worst in the world, warns UN. [Online] Dalam: https://news.un.org/en/story/2019/02/1032811

UNICEF, 2019. Yemen crisis: What you need to know. [Online]

Dalam: https://www.unicef.org/emergencies/yemen-crisis

Walk Free Foundation, 2018. The Global Slavery Index 2018: Arab States Report, Perth: Walk Free Foundation.

World Bank, 2019. Yemen's Economic Update - April 2019. [Online]

Available at: https://www.worldbank.org/en/country/yemen/publication/economicupdate-april-2019 [Diakses September 2020].

Yemen Data Project, 2020. Data. [Online] Dalam: https://yemendataproject.org/data.html 